\title{
Short Communication / Nota Científica Three new records of Remijia (Cinchoneae, Rubiaceae) for the Brazilian Amazon and a new altitudinal record for Venezuela
}

\author{
Alessandra Marques de Paiva ${ }^{1,3}$, Tamara de Andrade Ferreira Vieira ${ }^{1}$, Ruy José Válka Alves ${ }^{2}$ \\ \& Nílber Gonçalves da Silva ${ }^{2}$
}

\begin{abstract}
We present three new records of Remijia (Rubiaceae) for Brazil. Remijia globosa and R. reducta were known only from Venezuela and $R$. hispida from Venezuela and Colombia. During a revisional study of the genus, we found these three species had also been collected in the state of Amazonas, Brazil. Additionally, we found a collection of $R$. hispida from Venezuela, near La Esmeralda, at an altitude over 2,000 m higher than previously known for this species. This contributes to the knowledge of Remijia distribution, especially in the Amazon basin and in the Brazilian part of the Guiana Shield.

Key words: altitudinal distribution, Amazon Basin, floras, Guiana Shield.

Resumo

Apresentamos três novos registros de Remijia (Rubiaceae) para o Brasil. Remijia globosa e R. reducta eram apenas conhecidas da Venezuela e $R$. hispida da Venezuela e Colômbia. Durante a revisão do gênero, descobrimos que essas espécies também haviam sido coletadas no estado do Amazonas, Brasil. Adicionalmente, encontramos uma coleta de R. hispida da Venezuela, próximo a La Esmeralda, numa área mais de $2.000 \mathrm{~m}$ acima das altitudes dos registros anteriormente conhecidos. Isso contribui com o conhecimento da distribuição de Remijia, especialmente na Bacia Amazônica e na parte brasileira do Escudo das Guianas.

Palavras-chave: distribuição altitudinal, Bacia Amazônica, floras, Escudo das Guianas.
\end{abstract}

According to the WCSP (2018) Remijia DC. includes ca. 43 shrub and tree species occurring in South America. They are found in Brazil, Bolivia, Colombia, Ecuador, Guyana, Peru and Venezuela, with a diversity center in the Amazon (Andersson 1992; Taylor \& Steyermark 2004). The species occur in the Amazon Basin, in the Guiana Shield and in the Brazilian Caatinga, Atlantic Rainforest, Campo Rupestre and Cerrado at altitudes of 50-2,130 (2,750) $\mathrm{m}$ above sea level (asl.).

The genus is characterized by erect interpetiolar stipules which are flatly appressed in the buds; axial thyrsoid inflorescences with either racemiform, spiciform, corymbiform, subcapitate, capitate forms or solitary flowers and winged seeds with entire to toothed margins.

While preparing a revisional study of Remijia, three species previously not recorded from Amazonian Brazil, Remijia globosa (Steyermark) C.M. Taylor, R. hispida Spruce ex K. Schum. and $R$. reducta Steyerm. came to our attention and their occurrences are reported here.

The terminology for characterization of vegetative and floral structures and texture followed Radford et al. (1974), Robbrecht (1988) and Harris \& Harris (2003), for the types of inflorescence Weberling (1977) and Andersson (1995), for inflorescence form (Taylor 2014) and

\footnotetext{
${ }^{1}$ Universidade Federal do Rio de Janeiro, Museu Nacional, Prog. Pós-graduação em Botânica, Quinta da Boa Vista s/n, São Cristóvão, 20940-040, Rio de Janeiro, RJ, Brazil.

${ }^{2}$ Universidade Federal do Rio de Janeiro, Museu Nacional, Depto. Botânica, Quinta da Boa Vista s/n, São Cristóvão, 20940-04, Rio de Janeiro, RJ, Brazil.

3 Author for correspondence: alessandrambot@gmail.com
} 
for fruits Barroso et al. (1999) and Andersson (1995). Herbarium acronyms follow Thiers (continuously updated).

Three species of Remijia are reported for the first time to the Brazilian territory, all of them from the Amazonas state, within the Amazon domain. Additionally, a noteworthy collection of R. hispida from the Venezuelan highlands was found (Fig. 1).

1. Remijia globosa (Steyerm.) C.M. Taylor, Flora of the Venezuelan Guayana 8: 782-783. 2004.

Fig. 2

Trees or shrubs 3-8 $\mathrm{m}$ tall; stems quadrangular, thickened, hollow with ants, branches tomentose. Stipules obovate, rotund, 5-7 $\times 2.8-3.9 \mathrm{~cm}$, free, externally densely tomentose, not dilated. Leaves opposite; blades obovate, 30-40 × 10.4-19.2 cm, cordate to rotund at the base, obtuse at the apex, chartaceous, glabrescent to tomentose adaxially, sometimes rugose, tomentose abaxially, entire margin, plane; secondary veins $13-20$ on each side; domatia absent; petioles $1.3-4 \mathrm{~cm}$ long, not winged, without domatia, tomentose. Inflorescence capitate, multifloral, 20-35 × 2-6 cm; penducles
18-30 cm long, tomentose; bracts $3-4 \mathrm{~cm}$ long, ovate, rotund, involucral, deciduous, tomentose. Flowers not seen. Infructescence with involucral bracts absent. Capsules sessile, oblong, septicidal, externally costate, striate, sericeous, 8-20 × 3-9 $\mathrm{mm}$, dehiscence basipetal, chartaceous; seeds numerous, $1-2 \times 0.1-0.2 \mathrm{~mm}$, margins entire.

Examined material: BRAZIL. AMAZONAS: Parque Nacional do Pico da Neblina, Serra do Pirapucu, 24.III.1975, fr., M.R. Cordeiro 322 (IAN). VENEZUELA. AMAZONAS: Cerro de la Neblina, Rio Yatua, Caño Grande SSW of Cumbre Camp, 24.XII.1957, fr., Maguire et al. 42467 (holotype: NY); Cerro Neblina south face of Pico Phelps massif, 13.IV.1984, fr., A. Gentry \& B. Stein 46590 (MO, VEN).

Remijia globosa was until now considered endemic to Venezuela, occurring in Cerro Neblina (state of Amazonas) at altitudes of 1,100-1,400 m above sea level (Taylor \& Steyermark 2004). In Brazil it is found in the state of Amazonas in Serra de Pirapucu and grows in borders of igarapés, in high altitudes $(2,130 \mathrm{~m})$. The Serra de Pirapucu is located in the Pico da Neblina National Park which is the highest peak in the Brazilian part of the Guiana Shield. This study extends the altitudinal

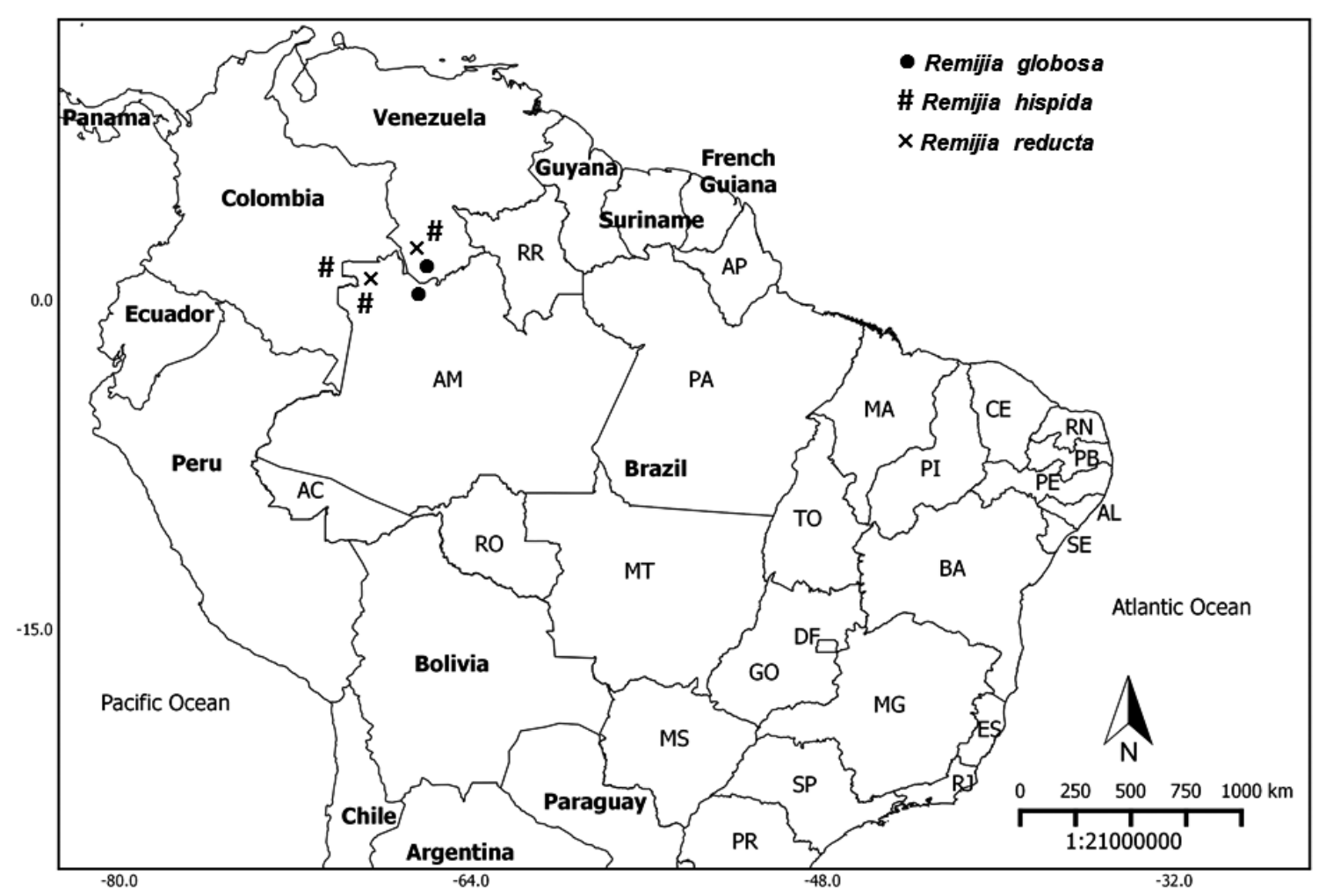

Figure 1 - Distribution map of Remija globosa (Steyerm.) C.M. Taylor, Remijia hispida Spruce ex K. Schum. and Remijia reducta Steyerm. 
ranges of $R$. globosa by $730 \mathrm{~m}$ upwards in Brazil. By the capitate inflorescences and habit, $R$. globosa resembles $R$. aracamuniensis, also known from Venezuela. However, $R$. aracamuniensis, has corolla white (vs. pink); hirsute to villous branches (vs. tomentose); adaxially hirsute, coarse, and abaxially hirsute to villous leaves (vs. tomentose). The two species have been recorded as sympatric.

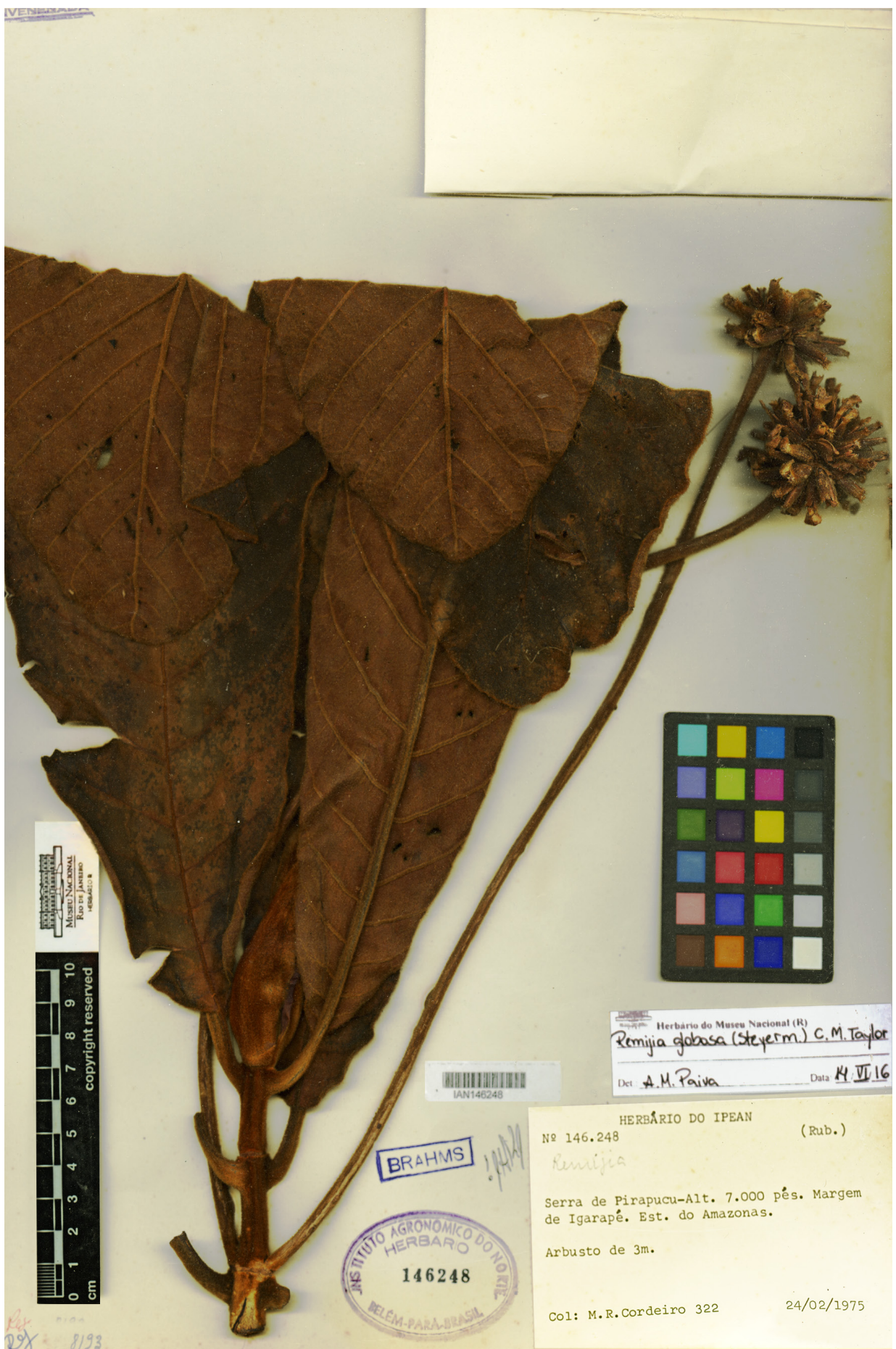

Figure 2 - Remija globosa (Cordeiro 322). 
2. Remijia hispida Spruce ex K. Schum. Flora Brasiliensis 6(6): 150. 1889.

Fig. 3

Treelets or shrubs $1-10 \mathrm{~m}$ tall; stems cylindrical, slender, solid, branches hirsute to hispid. Stipules linear to lanceolate, $2-3 \times$ $0.4-0.6 \mathrm{~cm}$, free, externally hirsute, not dilated. Leaves opposite; blades elliptical, oblong to lanceolate, 5.5-17 × 3-6 cm, obtuse at the base, acute to acuminate at the apex, subcoriaceous, hispid adaxially, hirsute abaxially, margins entire, revolute, secondary veins $10-16$ on each side, without domatia; petioles 9-25 mm long, not winged, without domatia, hirsute. Inflorescence racemiform or/and spiciform, pauciflorous, 10-17 $\times 3-6 \mathrm{~cm}$; peduncles 5-11 cm long, hirsute; bracts 3-4 cm long, triangular, involucral, deciduous, externally hispid. Flowers 5-merous, sessile or pedicellate 1-2 mm long, hispid; hypanthium ca. $1 \mathrm{~mm}$ long. Calyx lobes triangular, 1-2 mm long, irregular, vertically, unilaterally, totally split, $8-10$ $\times 0.2-0.4 \mathrm{~mm}$, tube basally pubescent inside, hispid outside, colleters absent. Corolla 3-4.3 $\times 0.1-0.2$ $\mathrm{cm}$, white, tube glabrous inside, hispid outside, lobes 5-6 mm long, linear. Stamens 5, included or exserted, 10-15 mm long; anthers 4-5 mm long. Ovary inferior, 2-locular, ovules numerous in each locule, ca. $1.5 \mathrm{~mm}$ long; stigma 1-2 $\mathrm{mm}$, styles glabrous; nectary disk ca. $1 \mathrm{~mm}$ long, annular. Infructescence lacking involucral bracts. Capsules globose, partly loculicidal, externally costate, hispid, $1-2 \times 0.6-0.8 \mathrm{~cm}$, dehiscence basipetal, chartaceous; seeds numerous, 6-11 $\times 3-4 \mathrm{~mm}$, margin entire.

Selected material: BRAZIL. AMAZONAS: São Gabriel da Cachoeira, Região de Auaretê, Rio Negro, 15,VI.1975, fr., B.S. Pena 749 (IAN). COLOMBIA. VAUPÉS: Río Paraná Pichuna (tributary of Río Vaupés), IV.1953, fl., R.E. Schultes \& I. Cabrera 19923 (F); Mitú and vicinity, lower Río Paraná-pichuna, 8.IX.1976, fr., J.L. Zarucchi 1987 (INPA). VENEZUELA. AMAZONAS: ad fluvium Orinoco prope Esmeraldas, XII.1853, fr., Spruce 3248 (isotype K), Esmeralda, Orinoco, 09.X.1928, fr., Luetzelburg 22747 (R); Casiquiare, Piedra Arauicaua, Rio Yatua, 27.IX.1957, fr., B. Maguire et al. 41609 (RB); Departamento Atabapo, 3 km al N-W de la Esmeralda, 26.II.1990, fr., G. Aymard \& L. Delgado (MO), alrededores de la Esmeralda, en riberas del Alto Río Orinoco, 28.I-8.II.1975, fl. e fr., N.R. Ferrigni et al. $27 E$ (HB).

Remijia hispida was initially reported from Venezuela and Colombia, growing on sandstone, quartzite and gneiss-granitic rock outcrops, from altitudes between 100 and $600 \mathrm{~m}$ asl. (Taylor \& Steyermark 2004). However, the specimen Ferrigni et al. 27E was collected growing in dry soil on rocks at $2,750 \mathrm{~m}$ asl., which significantly extends its altitudinal range. This study extends the altitudinal range of $R$. hispida by $2,150 \mathrm{~m}$ upward in Venezuela. In Brazil R. hispida grows in wet sandy soils in the Amazon basin at altitudes of ca. $100 \mathrm{~m}$ In habit, inflorescence shape, corolla color and indumentum this taxon resembles $R$. asperula, also known from the Brazilian state of Amazonas. However, $R$. asperula can be distinguished mainly by a regularly lobed (vs. irregular lobed), unsplit calyx (vs. totally split) and capsules with acropetalous dehiscence (vs. basipetal dehiscence). There is an image available in the INCT/CRIA website (EAFM, 2018) of a collection made by Stropp \& Assunção (number 312) at São Gabriel da Cachoeira (Amazonas, Brazil) in 2007, deposited in the EAFM (Manaus) Herbarium. This specimen possibly belongs to Remijia hispida, however, we could not have physical access to the material, thus a precise determination was not possible.

3. Remijia reducta Steyerm. Annals of the Missouri Botanical Garden 76: 968. 1989. Fig. 4

Shrubs 0.5-9 m tall; stems cylindrical, slender, solid, branches hirsute. Stipules ovate to oblong, 10-20 × 4-14 mm, externally densely hirsute, not dilated. Leaves opposite; blades elliptic, lanceolate or oblong, 3.4-12.2 × 1-4.3 cm, acute at the base, obtuse at the apex, chartaceous, rugose or bullate, glabrescent adaxially, densely hirsute to tomentose abaxially, margin entire, revolute; secondary veins $7-12$ on each side; domatia absent; petioles 1-10 $\mathrm{mm}$ long, not winged, lacking domatia, hirsute. Inflorescence with solitary flowers, $1-2 \times 0.9-1 \mathrm{~cm}$; peduncles 1-7 mm long, hirsute; bracts 1-3 mm long, linear, not involucral, persistent, hirsute. Flowers 5-merous, sessile, hirsute; hypanthium ca. $2 \mathrm{~mm}$ long. Calyx lobes triangular, $1 \mathrm{~mm}$ long, regular, not split, $1-2 \times 1-2 \mathrm{~mm}$, tube glabrous inside, hirsute outside, internally with colleters at the base. Corolla $2-2.5 \times 0.1-0.2 \mathrm{~cm}$, white, tube glabrous inside, hirsute outside, lobes 10-12 mm long, linear to lanceolate. Stamens 5 , included or exserted, 7-8 $\mathrm{mm}$ long; anthers $3 \mathrm{~mm}$ long. Ovary inferior, 2-locular, ovule numerous in each locule, 3-4 m long; stigma $2 \mathrm{~mm}$, styles glabrous; nectary disk ca. $1 \mathrm{~mm}$ long, annular. Infructescence similar to inflorescence. Capsules oblong to obovate, partially loculicidal, externally costate, striate, hirsute, 1-3 × 1-2 cm, dehiscence basipetal, chartaceous; seeds numerous, $5-8 \mathrm{~mm}$ long, with entire margins. 


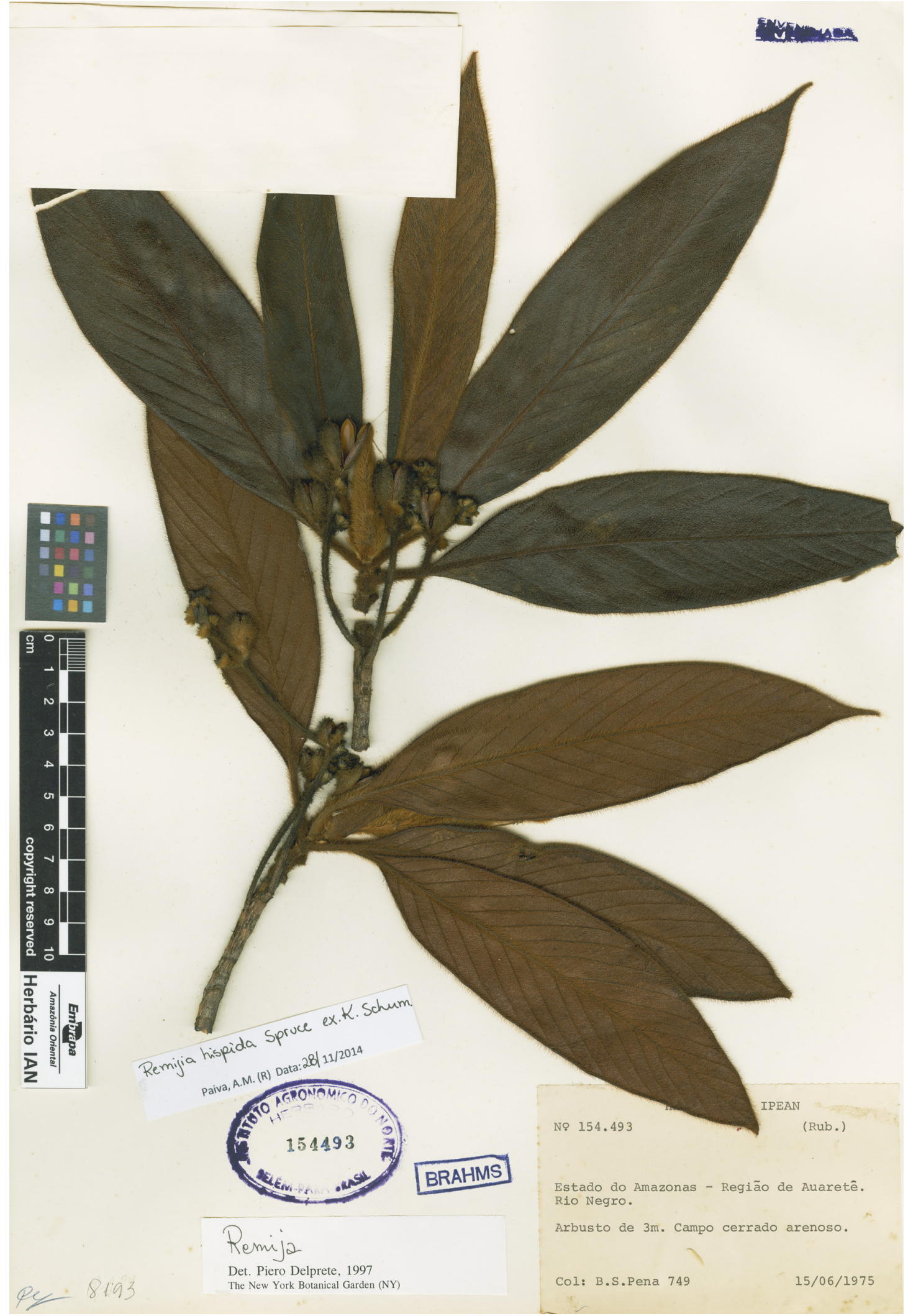

Figure 3 -Remija hispida (Pena 749). 
Examined material: BRAZIL. AMAZONAS: São Gabriel da Cachoeira, Iauareté, 18.V.1975, fr., B.G.S. Ribeiro 954 (MG); Alto Rio Negro, Rio Uaupés, 18.V.1975, fl., L. Coelho 19 (INPA). VENEZUELA. AMAZONAS: Departamento Rio Negro, Cerro Aracamuni, summit, 17.X.1987, fr., R. Liesner \& F. Delascio 22045 (paratype MO).
To date Remijia reducta was considered endemic to Venezuela, growing in wet rain forest and tepui meadows from 1,400 to $1,600 \mathrm{~m}$ asl. (Taylor \& Steyermark 2004). In Brazil it is found in the state of Amazonas (São Gabriel da Cachoeira) at an altitude of ca. $90 \mathrm{~m}$ asl. in the Amazon basin.

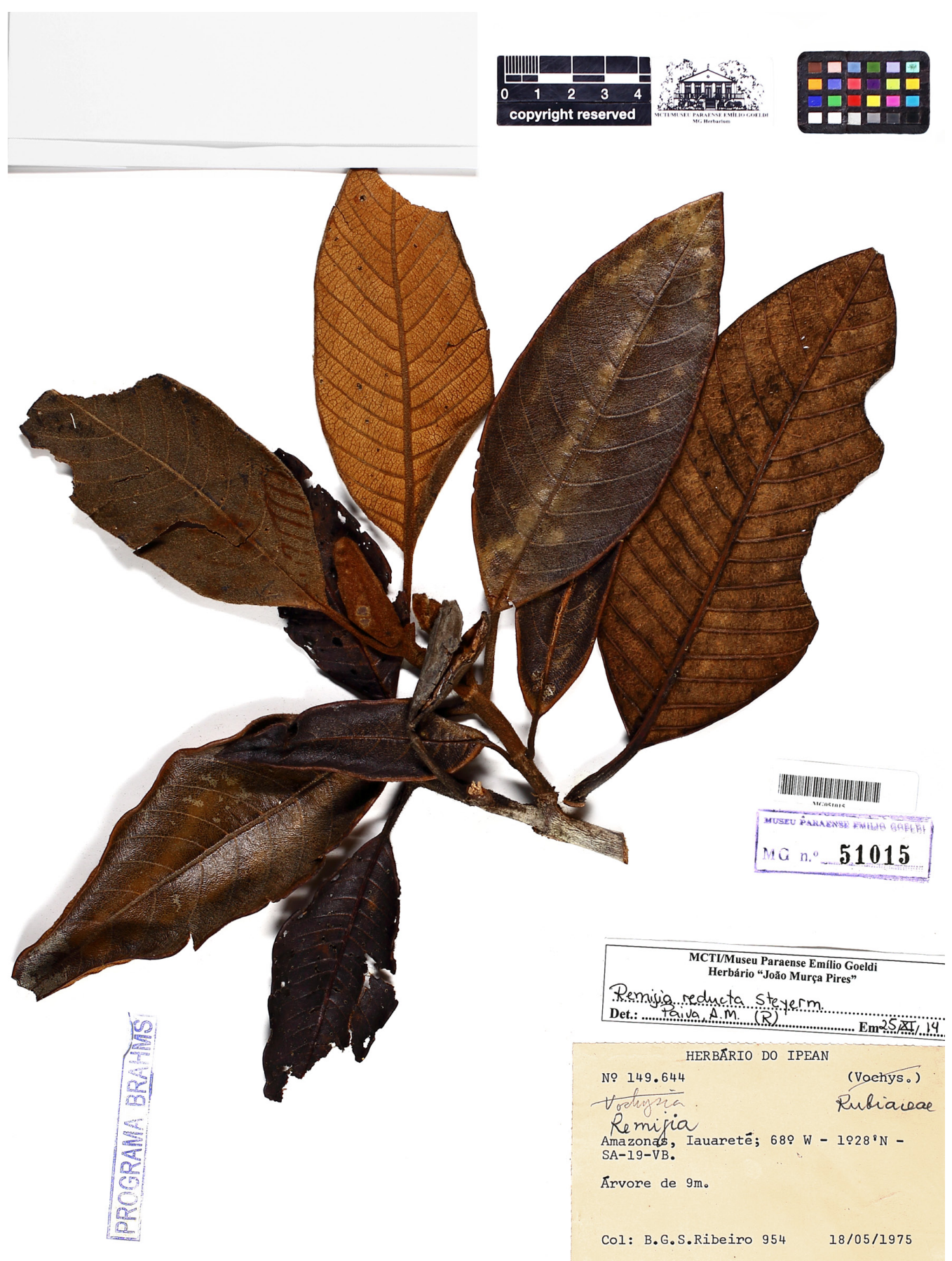

Figure 4 - Remijia reducta (Ribeiro 954). 
This study extends the altitudinal range of $R$. reducta by $1,310 \mathrm{~m}$ downward in Brazil. This taxon resembles the Venezuelan $R$. uniflora with which it shares solitary flowers. However, $R$. uniflora has glabrous branches (vs. vestite), coriaceous leaves with flat margins ( $v s$. chartaceous; revolute); ligulate stipules (vs. ovate to oblong) and septicidal capsules (vs. partly loculicidal).

The three specimens were collected in 1975 , by different collectors, and their correct determination was made four decades later. The three new occurrences herein show us how poorly studied the flora of the Brazilian Amazon remains.

The authors are thankful to the curators of cited herbaria for access to collections and/or loans of material, to the curators and employees of herbaria MG and IAN for sending images of specimens, to CAPES for scholarships to AMP and TAFV, to FAPERJ for supporting field and laboratory works, and the two anonymous reviewers, whose comments helped improve the manuscript.

\section{References}

Andersson L (1992) A Provisional Checklist of Neotropical Rubiaceae. Scripta Botanica Belgica 1: 1-199.

Andersson L (1995) Tribes and genera of the Cinchoneae complex (Rubiaceae). Annals of the Missouri Botanical Garden 82: 409-427.

Barroso GM, Morim MP, Peixoto AL \& Ichaso CLF (1999) Frutos e sementes: morfologia aplicada à sistemática de dicotiledôneas. Editora Universidade Federal de Viçosa, Viçosa. 443p.
EAFM (2018) Herbário do Instituto Federal de Educação, Ciência e Tecnologia do Amazonas (EAFM) disponível na rede speciesLink. Available at $<$ http:// www.splink.org.br>. Access on 21 February 2018.

Harris JG \& Harris MW (2003) Plant identification terminology: an illustrated glossary. $2^{\text {nd }}$ ed. Spring Lake Publishing, Spring Lake. 216p.

Radford AE, Dickison WC, Massey JR \& Bell CR (1974) Vascular plant systematics. Harper \& Row Publishers, New York. 891p.

Robbrecht E (1988) Tropical woody Rubiaceae. Characteristic features and progressions. Contributions to a new subfamilial classification. Opera Botanica Belgica 1: 1-127.

Taylor CM (2014) Remijia. Tropicos.org. Missouri Botanical Garden. Available at $<\mathrm{http}$ ://www.tropicos. org/Name/40023670>. Access on 03 May 2017.

Taylor CM \& Steyermark JA (2004) Remijia. In: Steyermark JA, Berry PE, Yatskievych K \& Holst BK (eds.) Flora of the Venezuelan Guayana. Vol. 8. Missouri Botanical Gardens Press, St. Louis. Pp. 779-792.

Thiers B [continuously updated] Index Herbariorum: a global directory of public herbaria and associated staff. New York Botanical Garden's Virtual Herbarium. Available at $<$ http://sweetgum.nybg. org/science/ih/>. Access on 01 May 2017.

WCSP (2018) World checklist of selected plant families. Royal Botanic Gardens, Kew. Available at $<$ http:// wcsp.science.kew.org/qsearch.do>. Access on 20 February 2018.

Weberling F (1977) Beitrage zur Morphologie der Rubiaceen-Inforeszenzen. Berichte der Deustscen Botanischen Gesellschaft 90: 191-209. 